\title{
Calmodulin-Dependent Regulation of Overexpressed but Not Endogenous TMEM16A Expressed in Airway Epithelial Cells
}

\author{
Khaoula Talbi, Jiraporn Ousingsawat, Raquel Centeio, Rainer Schreiber (D) and Karl Kunzelmann *(D) \\ Physiological Institute, University of Regensburg, University Street 31, D-93053 Regensburg, Germany; \\ khaoula.talbi@vkl.uni-regensburg.de (K.T.); jiraporn.ousingsawat@vkl.uni-regensburg.de (J.O.); \\ raquel.centeio@vkl.uni-regensburg.de (R.C.); rainer.schreiber@vkl.uni-regensburg.de (R.S.) \\ * Correspondence: karl.kunzelmann@ur.de; Tel.: +49-(0)941-943-4302; Fax: +49-(0)941-943-4315
}

check for updates

Citation: Talbi, K.; Ousingsawat, J.; Centeio, R.; Schreiber, R.;

Kunzelmann, K. CalmodulinDependent Regulation of

Overexpressed but Not Endogenous TMEM16A Expressed in Airway Epithelial Cells. Membranes 2021, 11, 723. https://doi.org/10.3390/ membranes 11090723

Academic Editor: Julia Schumann

Received: 13 August 2021

Accepted: 20 September 2021

Published: 21 September 2021

Publisher's Note: MDPI stays neutral with regard to jurisdictional claims in published maps and institutional affiliations.

Copyright: (c) 2021 by the authors. Licensee MDPI, Basel, Switzerland. This article is an open access article distributed under the terms and conditions of the Creative Commons Attribution (CC BY) license (https:/ / creativecommons.org/licenses/by/ $4.0 /)$.

\begin{abstract}
Regulation of the $\mathrm{Ca}^{2+}$-activated $\mathrm{Cl}^{-}$channel TMEM16A by $\mathrm{Ca}^{2+} /$ calmodulin (CAM) is discussed controversially. In the present study, we compared regulation of TMEM16A by $\mathrm{Ca}^{2+} /$ calmodulin (holo-CAM), CAM-dependent kinase (CAMKII), and CAM-dependent phosphatase calcineurin in TMEM16A-overexpressing HEK293 cells and TMEM16A expressed endogenously in airway and colonic epithelial cells. The activator of the $\mathrm{Ca}^{2+} / \mathrm{CAM}$-regulated $\mathrm{K}^{+}$channel KCNN4, 1-EBIO, activated TMEM16A in overexpressing cells, but not in cells with endogenous expression of TMEM16A. Evidence is provided that CAM-interaction with TMEM16A modulates the Ca ${ }^{2+}$ sensitivity of the $\mathrm{Cl}^{-}$channel. Enhanced $\mathrm{Ca}^{2+}$ sensitivity of overexpressed TMEM16A explains its activity at basal (non-elevated) intracellular $\mathrm{Ca}^{2+}$ levels. The present results correspond well to a recent report that demonstrates a $\mathrm{Ca}^{2+}$-unbound form of CAM (apo-CAM) that is pre-associated with TMEM16A and mediates a $\mathrm{Ca}^{2+}$-dependent sensitization of activation (and inactivation). However, when using activators or inhibitors for holo-CAM, CAMKII, or calcineurin, we were unable to detect a significant impact of CAM, and limit evidence for regulation by CAM-dependent regulatory proteins on receptor-mediated activation of endogenous TMEM16A in airway or colonic epithelial cells. We propose that regulatory properties of TMEM16A and and other members of the TMEM16 family as detected in overexpression studies, should be validated for endogenous TMEM16A and physiological stimuli such as activation of phospholipase C (PLC)-coupled receptors.
\end{abstract}

Keywords: TMEM16A; calmodulin; CAMKII; calcineurin; $\mathrm{Ca}^{2+}$-activated $\mathrm{Cl}^{-}$channel; anoctamin 1; CAM

\section{Introduction}

In our earlier study we analyzed the regulation of the $\mathrm{Ca}^{2+}$-activated $\mathrm{Cl}^{-}$channel (CaCC) TMEM16A. We found that the channel can be activated by activators of $\mathrm{Ca}^{2+}$ / calmodulin (CAM)-regulated KCNN4 $\mathrm{K}^{+}$channels, such as 1-EBIO and riluzole [1]. In addition, we demonstrated that TMEM16A physically interacts with CAM. A subsequent report indicated that the anion selectivity of TMEM16A is dynamically regulated by the $\mathrm{Ca}^{2+} / \mathrm{CAM}$ complex [2]. This study showed that CAM reversibly increases the permeability ratio $\mathrm{P}_{\mathrm{HCO} 3} / \mathrm{P}_{\mathrm{Cl}}{ }^{-}$. Further support for a CAM-dependent regulation of TMEM16A came from an interesting study by the Colecraft team [3]. They described a $\mathrm{Ca}^{2+}$-unbound form of CAM (apo-CAM), which is pre-associated with TMEM16A or the paralogue TMEM16B channel complexes. Apo-CAM mediates a $\mathrm{Ca}^{2+}$ dependent sensitization of activation and $\mathrm{Ca}^{2+}$ dependent inactivation of TMEM16 channels [3,4]. Moreover, CAM-dependent activation and inactivation of TMEM16A had also been found in an earlier study [5]. In contrast to these studies, other laboratories did not find evidence for regulation of TMEM16A by CAM or alteration of the bicarbonate permeability of TMEM16A by CAM [6,7].

While direct a CAM-regulation of TMEM16A is discussed controversially, several studies demonstrate that CAM-dependent kinase II (CAMKII) regulates CaCC/TMEM16A. However, CAMKII was found to activate [8-12] and to inhibit [13-17] CaCC and TMEM16A, 
respectively. Greenwood and Leblanc found a cell-type-dependent activation/inhibition of CaCC by CAMKII [18], while Ko et al. found differential regulation of TMEM16A by CAMKII, depending on the splice variant $[19,20]$. One study showed modulation of TMEM16 $\mathrm{A} \mathrm{Cl}^{-}$currents by CaMKII $\gamma$ phosphorylation at serine residues in TMEM16A. Serine525 and Serine727 in TMEM16A were mutated to alanine, but only mutation at Ser727 (S727A) reversed the CaMKII $\gamma$ inhibition of the TMEM16A Cl- current [15].

Earlier studies describe a crosstalk between $\mathrm{Ca}^{2+} / \mathrm{CAMKII-dependent} \mathrm{regulation}$ and inositol $(3,4,5,6)$-phosphate dependent regulation of $\mathrm{CaCC}$, which also appears to be cell-type-dependent, possibly explaining some of the controversial findings outlined above [21,22]. In our earlier study, we observed that regulation of TMEM16A by INO-4995, a lipid inositol phosphate, differs depending on whether the channel is overexpressed in mammalian cells such as HEK293, or whether regulation of endogenous TMEM16A is examined [23]. While overexpressed TMEM16A was potently activated by the inositol phosphate INO-4995, endogenous TMEM16A expressed in airway and colonic epithelial cells was not. Activation of endogenous TMEM16A by purinergic receptor stimulation was augmented by INO-4995 [23]. Along the same line, the membrane permeable dioctanoyl-PIP 2 phosphatidylinositol 4,5-bisphosphate-diC8 activated overexpressed TMEM16A, but did not touch endogenous TMEM16A [24]. Furthermore, other previously reported activators of TMEM16A such as melittin or cinnamaldehyde failed to activate endogenous TMEM16A. These differences prompted us to compare the role of CAM for acute receptor-mediated activation of TMEM16A in overexpressing cells and epithelial cells with endogenous expression of TMEM16A. Here, we made use of four different cell lines. HEK293 cells were used to study regulation of overexpressed TMEM16A, while airway epithelial cells (BCi_NS1, CFBE) and colonic $\mathrm{HT}_{29}$ cells were used to study regulation of endogenous TMEM16A. We demonstrate the absence of a significant CAM-dependent regulation for endogenous TMEM16A, solidifying the conclusion that control by CAM and other regulatory properties are indeed different for endogenous and overexpressed TMEM16A. Moreover, we made use of independent techniques (patch clamp, Ussing chamber, YFP-quenching) to reduce the chance for misinterpretations due to methodological artefacts. The data suggest only a minor role of CAM and the CAM-dependent proteins CAMKII and calcineurin for activation of endogenous TMEM16A, while CAM is likely to enhance $\mathrm{Ca}^{2+}$ sensitivity of overexpressed TMEM16A.

\section{Materials and Methods}

\subsection{Cell Culture}

All cells were grown at $37^{\circ} \mathrm{C}$ in a humidified atmosphere with $5 \%(\mathrm{v} / \mathrm{v}) \mathrm{CO}_{2}$. Culture conditions for CFBE and $\mathrm{HT}_{29}$ cells have been described earlier [25]. In brief, airway epithelial cells were grown in DMEM/Ham's F-12 with L-Glutamine medium supplemented with $10 \%(\mathrm{v} / \mathrm{v})$ fetal bovine serum (FBS), $1 \%(\mathrm{v} / \mathrm{v})$ L-glutamine $200 \mathrm{mM}$ and $1 \%(\mathrm{v} / \mathrm{v})$ HEPES 1M (all from Capricorn Scientific, Ebsdorfergrund, Germany). CFBE parental cells were grown in MEM with Earle's Salts with L-Glutamine medium (Capricorn Scientific, Ebsdorfergrund, Germany) supplemented with 10\% FBS. The airway epithelial cell line H441 was grown in RPMI and DMEM media. The immortalized human airway basal cell line BCi-NS1 (kindly provided by Prof. Ron Crystal, Weill Cornell Medical College, New York City, NY, USA) was maintained in Bronchial Epithelial Growth Media (Lonza). Cells were differentiated by growing on permeable supports (Snapwell, Corning, NY, USA) in an air-liquid interface (ALI) for up to 30 days in PnemaCult-ALI medium supplemented with PneumaCult-ALI 10X Supplement, PneumaCult-ALI Maintenance Supplement, hydrocortisone and heparin (all from StemCell Technologies, Vancouver, BC, Canada), and 1\% penicilin-steptomycin (10 $000 \mathrm{U} / \mathrm{mL}$; Gibco, ThermoFisherScientific, Waltham, MA, USA).

\section{2. $C D N A$, siRNA-TMEM16A, RT-PCR}

Construction of pcDNA31 human TMEM16A (abc) has been described previously [26]. Cells were transfected using standard protocols for Lipofectamine 3000. Knockdown 
of TMEM16A in CFBE parental cells was performed by transfecting siTMEM16A (5CCUGUACGAAGAGUGGGCACGCUAU-3, Invitrogen, Carlsbad, CA, USA) using standard protocols for Lipofectamine 3000 (Invitrogen, Carlsbad, CA, USA). Scrambled siRNA (Silencer ${ }^{\circledR}$ Select Negative Control siRNA \#1, Ambion, Austin, TX, USA) was transfected as negative control. All experiments were performed $72 \mathrm{~h}$ after transfection. For RT-PCR total RNA from HT29 and CFBE cells were isolated using NucleoSpin RNA II columns (Macherey-Nagel, Düren, Germany). Total RNA (0.5 $\mu \mathrm{g} / 25 \mu \mathrm{L}$ reaction) was reversetranscribed using random primer (Promega, Mannheim, Germany) and M-MLV Reverse Transcriptase RNase H Minus (Promega, Mannheim, Germany). Each RT-PCR reaction contained sense $(0.5 \mu \mathrm{M})$ and antisense primer $(0.5 \mu \mathrm{M})$ (Table 1), $0.5 \mu \mathrm{L}$ cDNA and GoTaq Polymerase (Promega, Mannheim, Germany). After 2 min at $95^{\circ} \mathrm{C}, \mathrm{cDNA}$ was amplified (targets 35 cycles, reference Gapdh 25 cycles) for $30 \mathrm{~s}$ at $95^{\circ} \mathrm{C}, 30 \mathrm{~s}$ at $56^{\circ} \mathrm{C}$, and $1 \mathrm{~min}$ at $72{ }^{\circ} \mathrm{C}$. PCR products were visualized by loading on Midori Green Xtra (Nippon Genetics Europe) containing agarose.

Table 1. Primers for PCR.

\begin{tabular}{ccc}
\hline Gene Accession Number & Primer & Size (bp) \\
\hline $\begin{array}{c}\text { TMEM16A (abcd) } \\
\text { NM_001378092.1 }\end{array}$ & \\
\hline Splice variant a & $\begin{array}{r}\text { s: 5'-GGACCCTGATGCCGAGTGC } \\
\text { as: 5'-GGAGAAGGGATAGGAGAGTC }\end{array}$ & 547 \\
\hline Splice variant b & $\begin{array}{r}\text { s: 5'-ACAGCAAAACCCGGAGC } \\
\text { as: 5'-TCTCTGGTCACACATCTCC }\end{array}$ & 462 \\
\hline Splice variant c & $\begin{array}{r}\text { s: 5'-ACAGCAAAACCCGGAGC } \\
\text { as: 5'-GGATGATCCTTGACAGCCTC }\end{array}$ & 703 \\
\hline Splice variant d & $\begin{array}{r}\text { s: 5'-GAAGAAAGAGTCCAGAAAC } \\
\text { as: 5'-CCGATCTCTCCATGTCAGC }\end{array}$ & 136 \\
\hline KCNN4 NM_002250.3 & $\begin{array}{r}\text { s: 5'-GATTTAGGGGCGCCGCTGAC } \\
\text { as: 5'-CTTGCCCCACATGGTGCCC }\end{array}$ & 405 \\
\hline Gapdh NM_001289726 & $\begin{array}{r}\text { s: 5'-GTATTGGGCGCCTGGTCAC } \\
\text { as: 5'-CTCCTGGAAGATGGTGATGG }\end{array}$ & 200 \\
\hline
\end{tabular}

\subsection{Patch Clamping}

Cells were patch-clamped after growing on coated glass coverslips for 2-3 days. Whole cell patch clamp techniques and data analysis have been described earlier [27]. In brief, patch pipettes were filled with a cytosolic-like solution containing (in $\mathrm{mM}$ ): $\mathrm{KCl} 30$, K-Gluconate 95, $\mathrm{NaH}_{2} \mathrm{PO}_{4} 1.2, \mathrm{Na}_{2} \mathrm{HPO}_{4}$ 4.8, EGTA 1, Ca-Gluconate 0.758, $\mathrm{MgCl}_{2} 1.03$, D-Glucose 5, ATP 3; pH 7.2. The intracellular (pipette) $\mathrm{Ca}^{2+}$ activity was $0.1 \mu \mathrm{M}$. Fast whole cell current recordings were performed as described recently [28]. The bath was perfused continuously with standard bicarbonate-free Ringer's solution (in mM: $\mathrm{NaCl}$ 145, $\mathrm{KH}_{2} \mathrm{PO}_{4} 0.4, \mathrm{~K}_{2} \mathrm{HPO}_{4} \cdot 3 \mathrm{H}_{2} \mathrm{O}$ 1.6, Glucose 5, $\mathrm{MgCl}_{2} \cdot 6 \mathrm{H}_{2} \mathrm{O}$ 1, Ca-Gluconate $1 \mathrm{H}_{2} \mathrm{O}$ 1.3) at a rate of $8 \mathrm{~mL} / \mathrm{min}$. Patch pipettes had an input resistance of 2-4 M $\Omega$ and whole cell currents were corrected for serial resistance. Currents were recorded using a patch clamp amplifier (EPC 7, List Medical Electronics, Darmstadt, Germany), the LIH1600 interface, and PULSE software (HEKA, Lambrecht, Germany), as well as Chart software (AD Instruments, Spechbach, Germany). Cells were stimulated with 1, 10, or $100 \mu \mathrm{M}$ ATP in standard bicarbonate-free Ringer's solution. Cells were current-clamped for most of the time. In regular intervals, membrane voltage $(V \mathrm{c})$ was clamped in steps of $20 \mathrm{mV}$ from -100 to $+100 \mathrm{mV}$. The inhibitor of $\mathrm{Ca}^{2+}$-activated $\mathrm{KCNN} 4 \mathrm{~K}^{+}$channels, if indicated TRAM$34(100 \mathrm{nM})$, was present in the patch clamp and other experiments to avoid contributions of $\mathrm{Ca}^{2+}$-activated $\mathrm{K}^{+}$channels. 


\subsection{Ussing Chamber}

Short circuit Ussing chamber measurements were performed on permeable supportgrown BCi-NS1 cells. Experiments were performed under short circuit Ussing chamber conditions (Physiological instruments) in the presence of $5 \% \mathrm{CO}_{2}$ and $25 \mathrm{mM} \mathrm{HCO}_{3}{ }^{-}$at $37^{\circ} \mathrm{C}$, as described earlier [29].

\subsection{YFP Quenching}

Cells stably transfected with iodide-sensitive YFP were plated in transparent 96-well plates (Sarstedt, Nümbrecht, Germany), cultured $24-72$ h to $80-90 \%$ confluence, washed with gluconate substituted-Ringer solution (mmol/L: $\mathrm{NaCl} 120$; $\mathrm{Na}^{+}$-gluconate 20; $\mathrm{KCl}$; $\mathrm{MgCl} 21 ; \mathrm{CaCl} 2$ 2; D-Glucose 10; HEPES 10), and incubated with or without test compounds in this solution. Total intracellular YFP fluorescence intensity in each well was measured in a fluorescence microplate reader (NOVOstar, BMG Labtech, Ortenberg, Germany) kept at $37^{\circ} \mathrm{C}$, using an excitation wavelength of $485 \mathrm{~nm}$ and emission detection at $520 \mathrm{~nm}$. Fluorescence was read continuously during injection of an iodide (I-)-substituted Ringer solution (mmol/L: $\mathrm{NaCl} 120 ; \mathrm{NaI} 20 ; \mathrm{KCl} 5 ; \mathrm{MgCl} 2$ 1; $\mathrm{CaCl} 2$ 2; D-Glucose 10; HEPES 10) by a syringe pump and following injections of a symmetrical Ringer solution (in mmol/L: $\mathrm{NaCl} 100-120 ; \mathrm{Na}^{+}$-Gluconate 10-20; $\mathrm{NaI} 10-20 ; \mathrm{KCl}$ 5; $\mathrm{MgCl} 2$ 1; $\mathrm{CaCl} 2$ 2; D-Glucose 10; HEPES 10) carrying test compounds. Original data were collected, background fluorescence was subtracted, and the initial rate of maximal fluorescence decay caused by I- influx/YFP fluorescence-quenching upon acute injection (or pre-incubation) of test compounds was measured to determine anion conductance/activity of TMEM16A.

\subsection{Materials and Statistical Analysis}

All compounds used were of highest available grade of purity and were obtained from Sigma-Aldrich (St. Louis, Missouri, USA), unless indicated otherwise. Data are shown as individual traces/representative images and/or as summaries with mean values \pm SEM, with the respective number of experiments given in each figure's legend. The population-effective sizes for the experiments were typically around $0.87-0.94$. As we did not want to rely on results obtained in one cell line only, we compared results obtained in overexpressing HEK293 cells with those obtained in cell expressing endogenous TMEM16A channels (CFBE, BCi-NS1, $\mathrm{HT}_{29}$ cells). For statistical analysis, paired or unpaired Student's $t$-test or ANOVA were used where appropriate. A $p$-value of $<0.05$ was accepted as a statistically significant difference.

\section{Results}

\subsection{Overexpressed TMEM16A Is Spontaneously Active Due to Enhanced $\mathrm{Ca}^{2+}$ Sensitivity}

We observed in earlier studies that TMEM16A, when overexpressed in HEK293 cells, produces whole cell currents in the presence of basal cytosolic $\mathrm{Ca}^{2+}$ concentrations of $0.1 \mu \mathrm{M}$ and with physiological concentrations of $\mathrm{K}^{+}, \mathrm{Na}^{+}$, and $\mathrm{Cl}^{-}$in the patch pipette filling solution [30,31] (Figure 1C,D). Such basal currents were not observed in cells expressing TMEM16A endogenously, such as $\mathrm{HT}_{29}$ colonic epithelial or CFBE airway epithelial cells [31] (Figure 1A,B). Here, TMEM16A was activated only after increase in the intracellular $\mathrm{Ca}^{2+}$ concentration, e.g., by application of the purinergic agonist ATP [31] (Figure 1A,B). In overexpressing cells, application of ATP activated whole cell currents in addition to the already enhanced basal currents. Enhanced and activated currents were inhibited by different blockers of TMEM16A such as CaCCinhAO1 (AO1) or niflumic acid $[1,30]$. Moreover, enhanced basal currents were inhibited by application of AO1 or in the absence of pipette (cytosolic) $\mathrm{Ca}^{2+}$, indicating that TMEM16A is in charge of both enhanced basal and ATP-activated currents (Figure 1E-H). These data strongly suggest a higher $\mathrm{Ca}^{2+}$ sensitivity of overexpressed TMEM16A when compared with endogenous TMEM16A. 
A

B
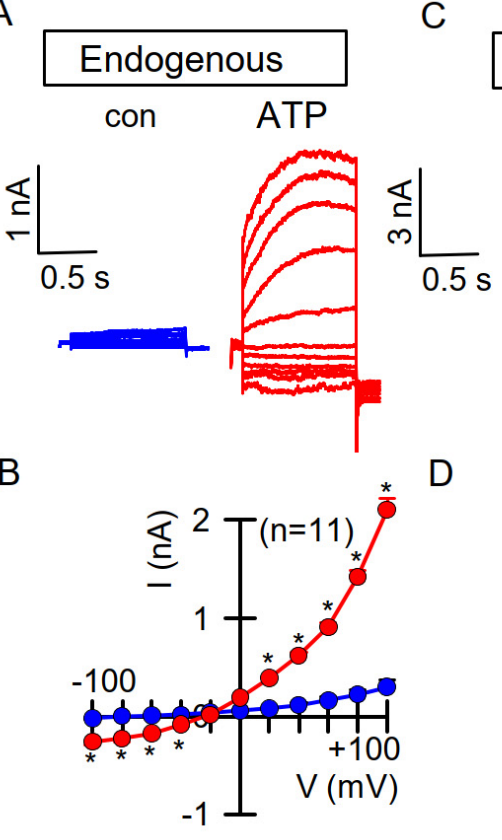

I

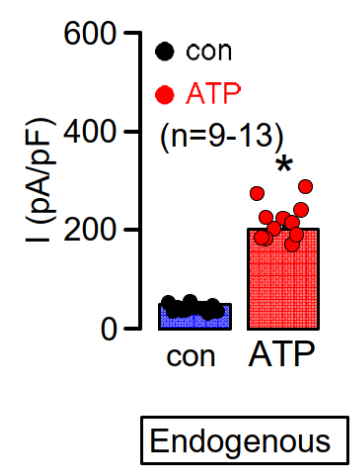

(
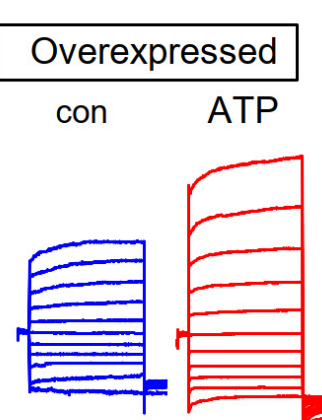

E

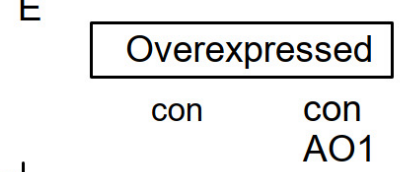

G

\begin{tabular}{|cc|}
\hline \multicolumn{2}{|c|}{ Overexpressed } \\
\hline $0.1 \mu \mathrm{M}$ & $0 \mu \mathrm{M}$ \\
$\mathrm{Ca}^{2+}{ }_{\mathrm{i}}$ & $\mathrm{Ca}^{2+}{ }_{\mathrm{i}}$
\end{tabular}

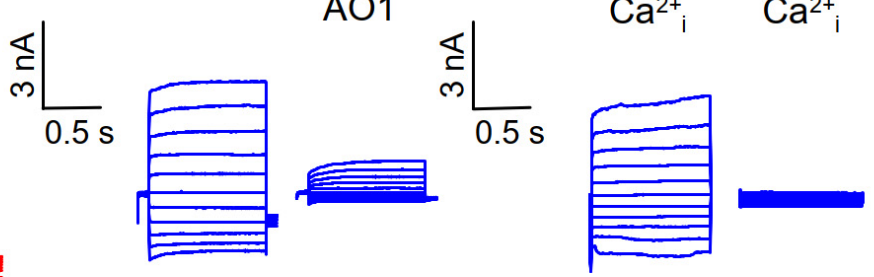

$\mathrm{F}$

$\mathrm{H}$

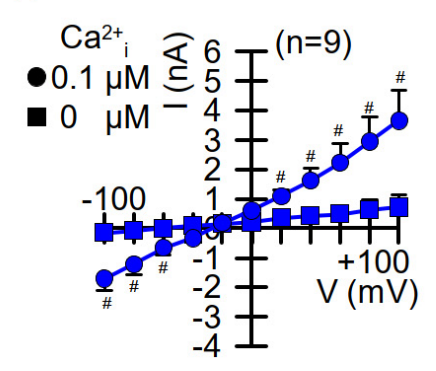

Figure 1. Overexpressed TMEM16A is spontaneously active due to enhanced $\mathrm{Ca}^{2+}$ sensitivity. TMEM16A whole cell currents were activated by $100 \mu \mathrm{M}$ ATP in CFBE airway epithelial cells expressing TMEM16A endogenously $(\mathbf{A}, \mathbf{B})$ and in HEK293 cells overexpressing TMEM16A (C,D). A,B) TMEM16A is closed under control conditions $\left(\left[\mathrm{Ca}^{2+}\right]_{\mathrm{i}}=0.1 \mu \mathrm{M}\right)$ and is opened by ATP-induced increase in $\left[\mathrm{Ca}^{2+}\right]_{\mathrm{i}} \cdot(\mathbf{C}, \mathbf{D})$ Whole cell currents were detected in TMEM16A-overexpressing cells under control conditions, with additional activation by ATP. (E,F) Whole cell currents detected under basal conditions were inhibited by the TMEM16A-blocker CaCCinhAO1 (AO1, $20 \mu \mathrm{M})$. (G,H) Whole cell currents detected under control conditions $\left(\left[\mathrm{Ca}^{2+}\right]_{\mathrm{i}}=0.1 \mu \mathrm{M}\right)$ were not detected in the absence of $\mathrm{Ca}^{2+}$ in the pipette filling solution. (I) Summary of the current densities. Mean \pm SEM ( $\mathrm{n}=$ number of experiments). * Significant activation by ATP and inhibition by AO1, respectively $\left(p<0.05\right.$; paired $t$-test). ${ }^{\#}$ Significant difference when compared to endogenous currents or in presence of $0 \mu \mathrm{M}$ $\left[\mathrm{Ca}^{2+}\right]_{\mathrm{i}}$, respectively $(p<0.05$; unpaired $t$-test).

To further demonstrate enhanced $\mathrm{Ca}^{2+}$ sensitivity of overexpressed TMEM16A, we performed patch clamp experiments in which we loaded the patch pipette with pipette filling solution containing different free $\mathrm{Ca}^{2+}$ concentrations. At $0 \mu \mathrm{M}$ pipette $\mathrm{Ca}^{2+}$ no TMEM16A, whole cell currents were observed in overexpressing HEK293 cells or CFBE cells expressing endogenous TMEM16A. Whole cell currents were activated in overexpressing HEK293 cells at $\mathrm{Ca}^{2+}$ concentrations as low as $0.01 \mu \mathrm{M}\left(10^{-8} \mathrm{M}\right)$, while TMEM16A currents in CFBE cells were only observed at $1 \mu \mathrm{M}\left(10^{-6} \mathrm{M}\right) \mathrm{Ca}^{2+}$, again strongly suggesting a higher $\mathrm{Ca}^{2+}$ sensitivity for overexpressed TMEM16A (Figure 2). At $10 \mu \mathrm{M} \mathrm{Ca}^{2+}$, whole cell currents were smaller due to the well-known $\mathrm{Ca}^{2+}$-dependent inactivation of TMEM16A [23]. No whole cell currents were activated in mock-transfected HEK293 cells. 

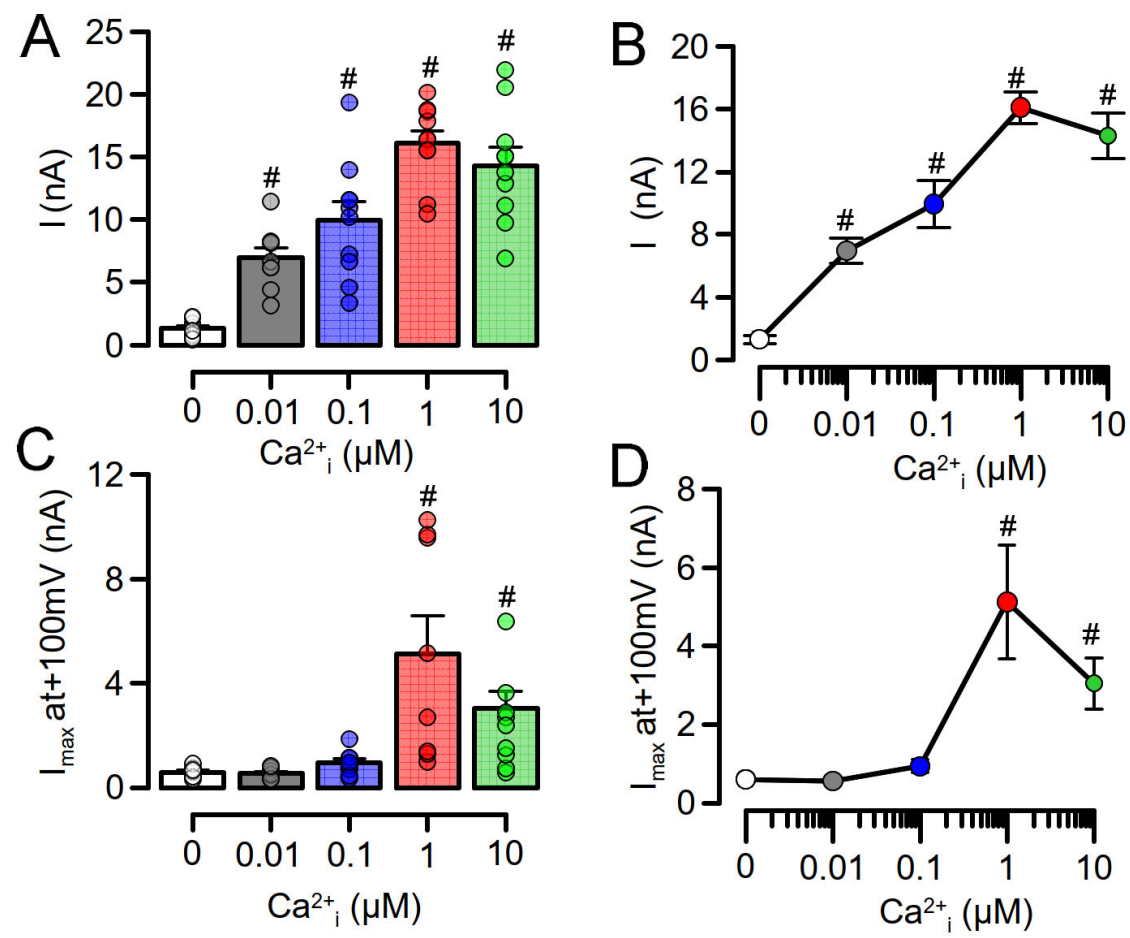

Figure 2. Enhanced $\mathrm{Ca}^{2+}$ sensitivity of overexpressed TMEM16A. Patch pipettes were filled with solutions containing different free $\mathrm{Ca}^{2+}$ concentrations $(0-10 \mu \mathrm{M})$. At $0 \mu \mathrm{M}$ pipette $\mathrm{Ca}^{2+}$ no TMEM16A, whole cell currents were observed in overexpressing HEK293 cells or CFBE cells expressing endogenous TMEM16A. (A,B) Whole cell currents were activated in overexpressing HEK293 cells at Ca ${ }^{2+}$ concentrations as low as $0.01 \mu \mathrm{M}$. (C,D) TMEM16A currents in CFBE cells were only observed at $1 \mu \mathrm{M} \mathrm{Ca}^{2+}$. Mean \pm SEM ( $\mathrm{n}=$ number of experiments). " Significant activation when compared to $0 \mu \mathrm{M} \mathrm{Ca}^{2+}(p<0.05 ;$ ANOVA).

\subsection{Enhanced $\mathrm{Ca}^{2+}$ Sensitivity of Overexpressed TMEM16A Is Modulated by CAM}

We previously reported regulation of TMEM16A by CAM [1], which, however, has been discussed controversially (c.f. Introduction). Here, we examined activation of overexpressed TMEM16A by the activator of the CAM/KCNN4 complex, 1-EBIO. No effects were seen for 1-EBIO in mock-transfected HEK293 cells. In contrast, TMEM16A-overexpressing cells showed enhanced basal currents, which were further augmented by 1-EBIO, clearly suggesting CAM-regulation of TMEM16A. Application of the CAM-inhibitor trifluoperazine (TFP) inhibited enhanced basal currents and attenuated activation by 1-EBIO. Moreover, the TMEM16A-inhibitor CaCCinhAO1 (AO1) [32] strongly inhibited enhanced basal currents and abolished the effect of 1-EBIO (Figure 3A-E). Finally, activation by 1-EBIO was examined in overexpressing HEK293 cells treated with scrambled RNA or with siRNA for CAM. Activation by 1-EBIO was attenuated in cells in which expression of CAM was knocked down (Figure $3 \mathrm{~F}, \mathrm{G})$. Knockdown of CAM was assessed by semiquantitative RT-PCR and was $94 \pm 2 \%(n=5)$. A similar number of CAM-transcripts are expressed in CFBE and HEK293 cells (Figure 3H). Notably, in contrast to TMEM16A-overexpressing HEK293 cells, no effect of siRNA-CAM was observed on the activation of TMEM16A in CFBE cells. These results suggest that enhanced basal TMEM16A currents are due to enhanced $\mathrm{Ca}^{2+}$ sensitivity, probably modulated by association of CAM with TMEM16A. 


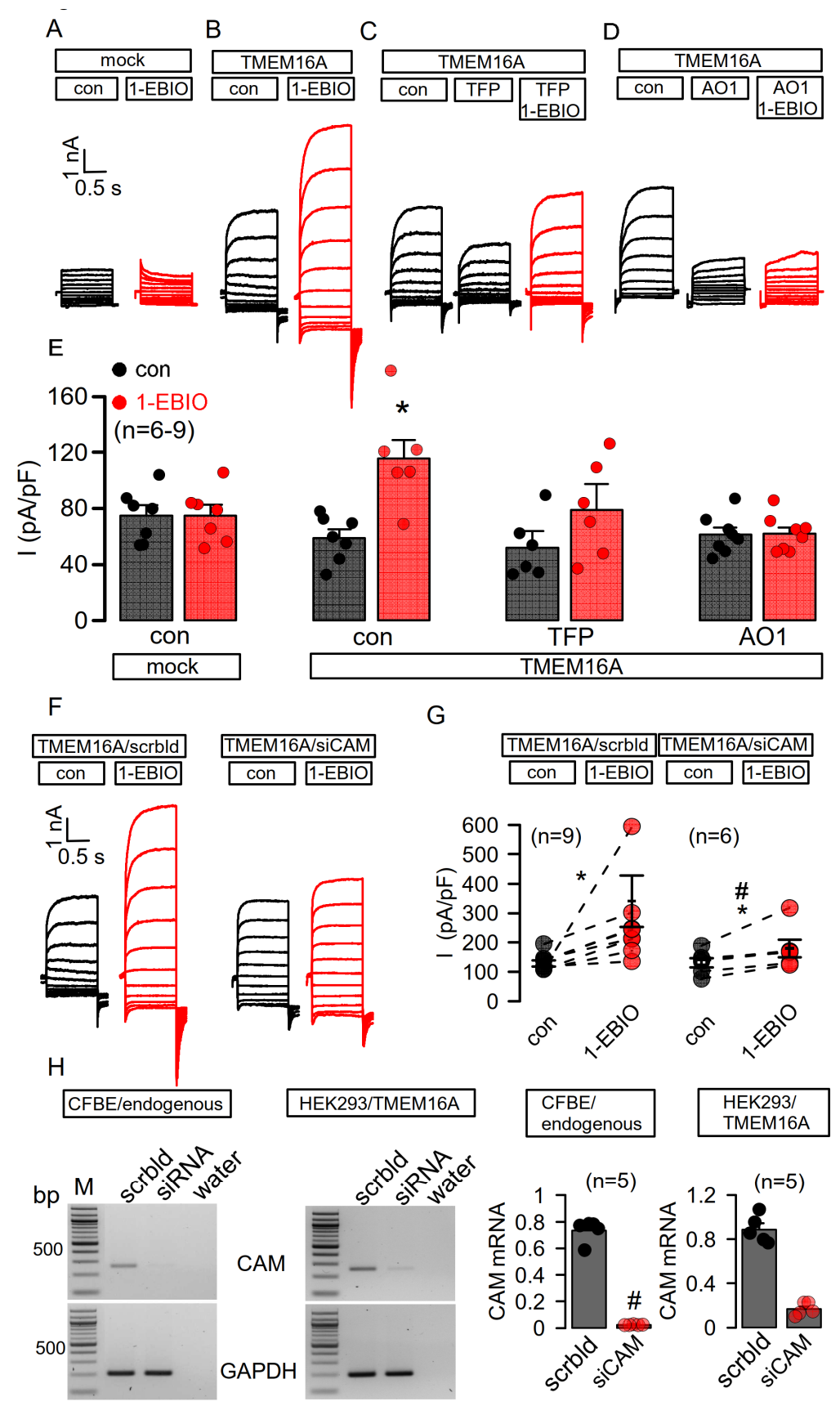

Figure 3. Enhanced $\mathrm{Ca}^{2+}$ sensitivity of overexpressed TMEM16A is mediated by CAM. (A-D) No effect of 1-EBIO (1 mM) on whole cell currents in mock-transfected HEK293 cells. Basal activity of TMEM16A and further activation by 1-EBIO in TMEM16A-overexpressing HEK293 cells. Inhibition of basal TMEM16A-activity and attenuation of the effect of 1-EBIO by the CAM-inhibitor trifluoperazine (TFP, $10 \mu \mathrm{M}$ ). Inhibition of basal TMEM16A-activity and inhibition of TMEM16A-activation by 1EBIO using CaCC-inhAO1 (AO1, $20 \mu \mathrm{M})$. (E) Summary of the current densities. (F,G) Basal activity of TMEM16A and further activation by 1-EBIO in overexpressing HEK cells treated with scrambled RNA (scrbld) or with siRNA for CAM (siCAM). (H) Knockdown of CAM was assessed by semiquantitative RT-PCR in both CFBE cells expressing endogenous TMEM16A and in HEK293 cells overexpressing TMEM16A. Similar number of CAM-transcripts are expressed in CFBE and HEK293 cells. Mean \pm SEM ( $\mathrm{n}=$ number of experiments). * Significant activation by 1 -EBIO and inhibition by AO1 or TFP, respectively ( $p<0.05$; paired $t$-test). " Significant difference when compared to activation in the absence of AO1, TFP, or siCAM, respectively ( $p<0.05$; unpaired $t$-test). 
3.3. No Activation of Endogenous TMEM16A by 1-EBIO and No CAMKII-Dependent Regulation of TMEM16A in Airway Epithelial Cells

We examined whether CAM-dependent regulation can also be detected for TMEM16A expressed endogenously in CFBE airway epithelial cells. Expression of TMEM16A in CFBE cells has been shown previously $[25,27]$. We also found expression of $\mathrm{Ca}^{2+}$-activated KCNN4 channels in CFBE (and H441) airway epithelial cells, but not in HEK293 cells (Figure 4A). Both CFBE and $\mathrm{HT}_{29}$ colon epithelial cells express the splice variant TMEM16Aa,b,c (Figure 4B). Patch clamp experiments were performed in the absence or presence of TRAM-34, a potent inhibitor of $\mathrm{Ca}^{2+}$-activated $\mathrm{KCNN} 4 \mathrm{~K}^{+}$channels. In the absence of TRAM-34, 1-EBIO activated a whole cell current and hyperpolarized the membrane voltage (Figure 4C,D). In contrast, in the presence of TRAM-34, no hyperpolarization was observed, and 1-EBIO did not activate whole cell currents (Figure 4E,F). Under both conditions, ATP activated whole cell currents. The data suggest that in airway epithelial cells with endogenous TMEM16A, 1-EBIO activates KCNN4 but not TMEM16A.

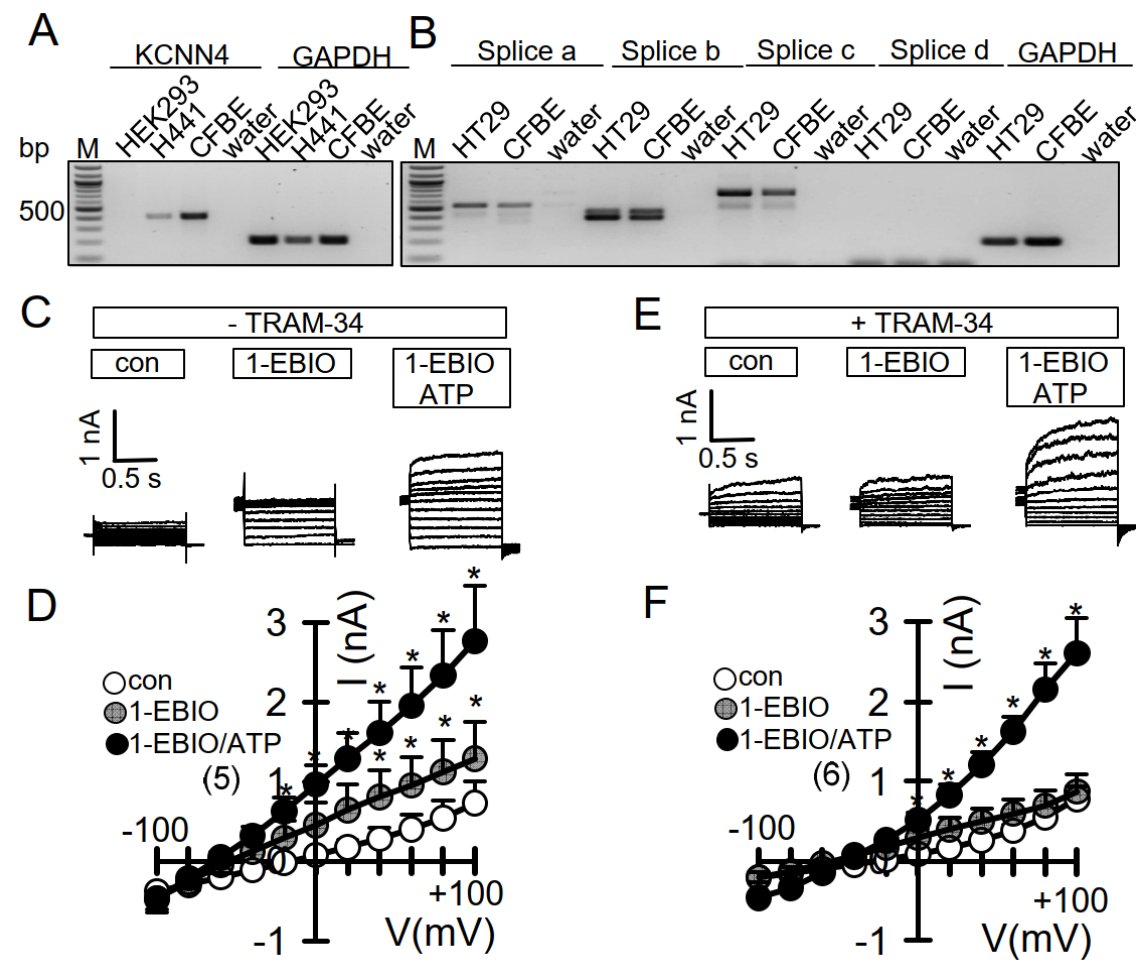

Figure 4. No activation of endogenous TMEM16A by 1-EBIO in CFBE airway epithelial cells. (A) RTPCR analysis indicating expression of $\mathrm{Ca}^{2+}$-activated KCNN4 channels in $\mathrm{H} 441$ and CFBE airway epithelial cells but not in HEK293 cells. (B) RT-PCR analysis indicating expression of the splice variant TMEM16Aa,b,c in $\mathrm{HT}_{29}$ colonic epithelial and CFBE airway epithelial cells. (C,D) Whole cell currents and current/voltage relationships demonstrating current activation and hyperpolarization by 1-EBIO $(1 \mathrm{mM})$ and additional activation by ATP $(100 \mu \mathrm{M})$. (E,F) Activation of whole cell currents and hyperpolarization by 1-EBIO is inhibited by the KCNN4 blocker TRAM-34 (100 nM). Mean \pm SEM ( $\mathrm{n}=$ number of experiments). ${ }^{*}$ Significant activation by 1 -EBIO and additional activation by $\operatorname{ATP}(p<0.05$; paired $t$-test).

Because CAM-dependent kinase (CAMKII) and the serine/threonine-phosphatase calcineurin require CAM to operate, we examined the effects of other CAM-activators (DCE$\mathrm{BIO}$, riluzole), CAMKII-inhibitors (KN-62, KN-93), and the calcineurin-inhibitor tacrolimus (FK-506) on basal and ATP-activated endogenous currents in airway epithelial cells. Notably, DCEBIO enhanced basal currents, and both DCEBIO and riluzole somewhat augmented ATP-activated currents but failed to reach significance (Figure 5A,B). Tacrolimus and inhibition of CAMKII attenuated ATP-activated currents. Taken together, apart from 
CAMKII-dependent activation, there is no clear evidence for CAM or calcineurin-dependent regulation of endogenous TMEM16A in CFBE airway epithelial cells.

A
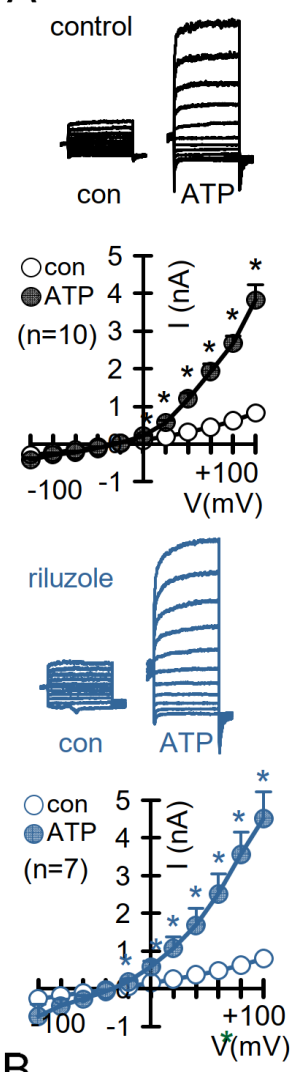

B
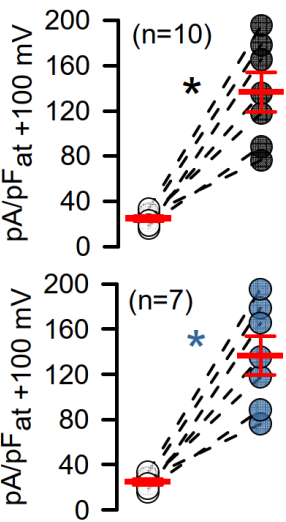
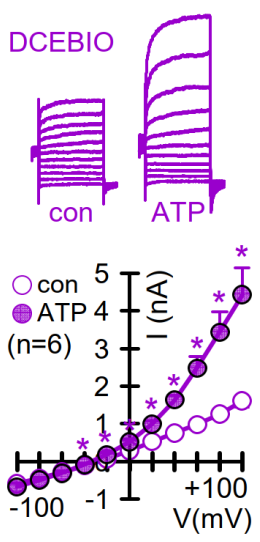

KN-62
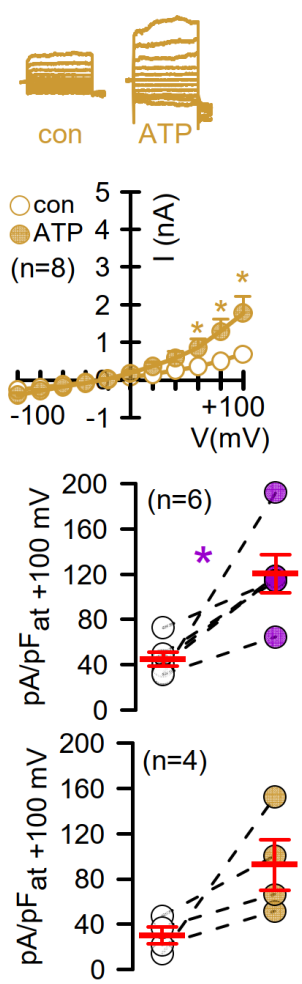

tacrolimus
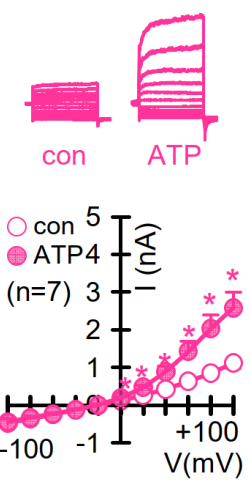

KN-93
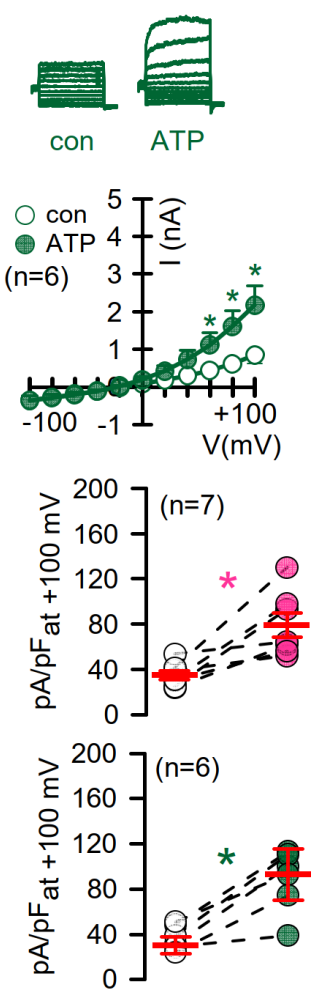

Figure 5. Evidence for CAMKII-dependent activation of TMEM16A but not for CAM- or calcineurindependent regulation of endogenous TMEM16A in CFBE airway epithelial cells. (A) Whole cell patch clamp analysis of ATP $(100 \mu \mathrm{M})$-activated TMEM16A currents and effects of the 1-EBIO analogues DCEBIO and riluzole (both $10 \mu \mathrm{M}$ ), the CAMKII-inhibitors KN-62 and KN-93 (both $10 \mu \mathrm{M}$ ) and the calcineurin inhibitor tacrolimus $(10 \mu \mathrm{M})$. Cells were pre-incubated with the compounds, which were also present during the experiment. Under all conditions, significant activation of whole cell currents by ATP was observed. While the KCNN4 activators DCEBIO and riluzole enhanced ATPactivated currents, KN-62, KN-93, and tacrolimus reduced current activation. The time course for ATP-activation of TMEM16A remained unchanged by the drugs. (B) Calculated current densities. All experiments were performed in the presence of the KCNN4-inhibitor TRAM-34. Mean $\pm \mathrm{SEM}$ ( $\mathrm{n}=$ number of experiments). * Significant activation by ATP $(p<0.05$; paired $t$-test). 


\subsection{No Evidence for CAM, CAMKII, or Calcineurin-Dependent Regulation of Endogenous} TMEM16A Expressed in Bci-NS1 Airway Epithelial Cells

In order to exclude cell-specific or methodological factors, we re-examined CAM, CAMKII, or calcineurin-dependent regulation in Ussing chamber recordings with human BCi-NS1 airway epithelial cells. When grown on permeable supports, these cells differentiate into a polarized epithelium with airway epithelial typical properties [25,33]. Cells were measured under control conditions or after exposure to KN-93, DCEBIO, or tacrolimus. Compounds were added subsequently to luminal or basolateral sides of the epithelium, and the effects of TRAM-34 (T-34), the epithelial $\mathrm{Na}^{+}$channel inhibitor amiloride (amil), the inhibitor of the cystic fibrosis transmembrane conductance regulator $\mathrm{Cl}^{-}$channel CFTRinh172 (Inh172), and ATP on short circuit currents (Isc) were examined. Neither $\mathrm{Na}^{+}$ absorption by ENaC nor basal $\mathrm{Cl}^{-}$currents by CFTR or ATP-activated TMEM16A/CFTR currents were significantly affected by any of the inhibitors (Figure 6).
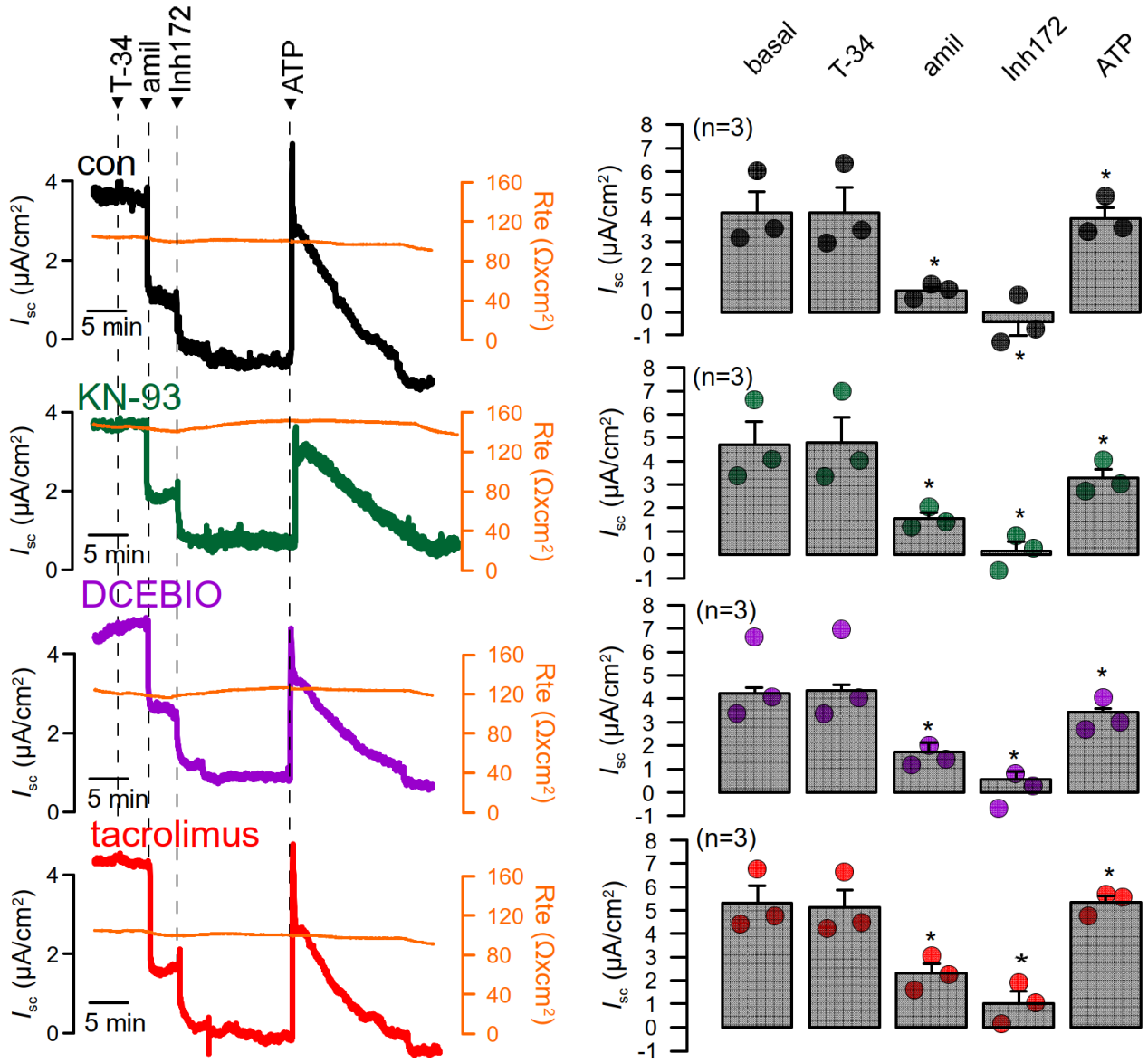

Figure 6. No evidence for CAM, CAMKII, or calcineurin-dependent regulation of endogenous TMEM16A in BCi-NS1 airway epithelial cells. Left panels: Ussing chamber recordings from human BCi-NS1 airway epithelial cells, assessing the ion transport by continuously measuring the transepithelial short circuit current Isc. Original continuous recordings of the short circuit currents Isc in the absence or presence of different inhibitors. The transepithelial resistance was continuously monitored in parallel. Cells were measured under control conditions or after exposure to KN-93 $(10 \mu \mathrm{M})$, DCEBIO $(10 \mu \mathrm{M})$, or tacrolimus $(100 \mathrm{nM})$. Right panels: Summaries for the short circuit currents corresponding to continuous Isc recordings shown in the left panels. The effects of TRAM-34 (T-34, $100 \mathrm{nM}$ ), amiloride (amil, $10 \mu \mathrm{M})$, CFTRinh172 (Inh172, $20 \mu \mathrm{M})$, and ATP $(5 \mu \mathrm{M})$ on Isc are summarized. Mean \pm SEM ( $\mathrm{n}=$ number of experiments). * Significant effects of amil, Inh172, and $\operatorname{ATP}(p<0.05$; paired $t$-test). 
3.5. No Evidence for CAM, CAMKII, or Calcineurin-Dependent Regulation of Endogenous TMEM16A in HT 29 Colonic Epithelial Cells

We finally examined if any of the inhibitors affect ATP-activated TMEM16A whole cell currents in $\mathrm{HT}_{29}$ colonic epithelial cells. Here, we used iodide quenching of halidesensitive yellow-fluorescent protein (YFP), stably expressed in $\mathrm{HT}_{29}$ cells. ATP-induced quenching in $\mathrm{HT}_{29}$ cells transfected with scrambled RNA was impressive (Figure 7A) and was completely abolished by siRNA-knockdown of TMEM16A (Figure 7B), indicating that TMEM16A was fully in charge of ATP, i.e., $\mathrm{Ca}^{2+}$-activated whole cell currents in $\mathrm{HT}_{29}$ cells. None of the inhibitors DCEBIO, KN-62, KN-93, riluzole, or tacrolimus, applied at different concentrations, affected current activation by ATP (Figure 7C,D). Taken together, the results suggest that CAM-dependent regulation of TMEM16A is present in overexpressing HEK293 cells but shows little effects on TMEM16A expressed endogenously in airway and colonic epithelial cells.

A

scrambled

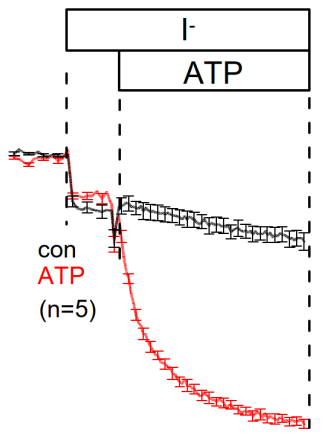

B SITMEM16A

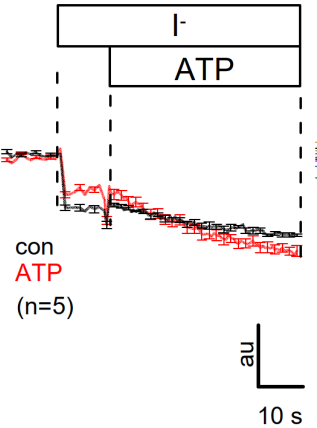

C

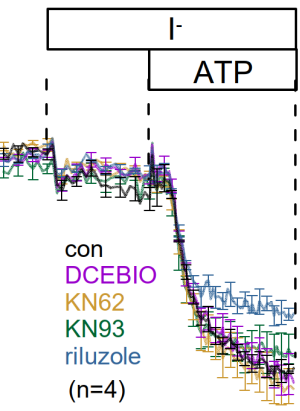

D

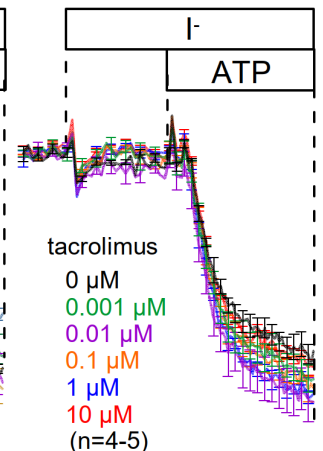

Figure 7. No evidence for CAM, CAMKII, or calcineurin-dependent regulation of endogenous TMEM16A in $\mathrm{HT}_{29}$ colonic epithelial cells. Iodide quenching of YFP stably expressed in $\mathrm{HT}_{29}$ colonic epithelial cells was used to assess $5 \mu \mathrm{M}$ ATP-activated halide permeability by activation of TMEM16A. (A) ATPinduced quenching in mock transfected $\mathrm{HT}_{29}$ cells. (B) ATP-induced quenching in $\mathrm{HT}_{29}$ cells with siRNA-knockdown of TMEM16A. (C) Preincubation of the cells with DCEBIO, KN-62, KN93, and riluzole (all $10 \mu \mathrm{M}$ ) did not affect ATP-induced quenching. (D) Incubation with different concentrations of tacrolimus did not affect ATP-induced quenching. All experiments were performed in the presence of TRAM-34. Mean \pm SEM ( $n=$ number of experiments). au = arbitrary units for fluorescence quenching.

\section{Discussion}

Regulation of the $\mathrm{Ca}^{2+}$-activated $\mathrm{Cl}^{-}$channel TMEM16A has been studied extensively. In most patch clamp studies, the channel is examined as overexpressed protein activated by high pipette $\mathrm{Ca}^{2+}$ in the presence of unphysiological salt concentrations and at $20^{\circ} \mathrm{C}[34,35]$. Our previous work showed that activation of TMEM16A by phosphatidylinositol 4,5-bisphosphate or inositol 3,4,5,6-tetrakisphosphate is well detected for overexpressed TMEM16A, but not for endogenous TMEM16A [23,24]. Moreover, other activators or inhibitors also show differential effects between overexpressed and endogenous channels [24]. The overexpressed channel is already active at basal intracellular (pipette) $\mathrm{Ca}^{2+}$ as low as $0.01 \mu \mathrm{M}$. This enhanced basal current is reduced at temperatures lower than $37^{\circ} \mathrm{C}[30,31]$. Notably, similar is observed for TMEM16F, which is a phospholipid scramblase and a nonselective ion channel [31]. Interestingly, the calcium-hypersensitive aspartic acid 408-to-glycine 408 (D408G) TMEM16F mutant showed spontaneous scrambling and ion channel activity when overexpressed in HEK293 cells, but both scrambling and ion currents were not enhanced in macrophages isolated from knockin-mice expressing D408G-TMEM16F instead of wt-TMEM16F [31,36] (data not shown). For both TMEM16A and TMEM16F, we proposed a role of lipid-dependent regulation modulating their $\mathrm{Ca}^{2+}$ 
sensitivity and activity at basal $\mathrm{Ca}^{2+}$ activity. Lipid-dependent regulation may depend on the ambient temperature and other factors such as temperature-sensitive phospholipase A2, reactive oxygen species, and the cytosolic (pipette) ion composition [31,37]. Moreover, we speculated earlier that i) massively overexpressed TMEM16A may end up in non-raft compartments, which are more accessible to other cellular $\mathrm{Ca}^{2+}$ sources, ii) overexpressed TMEM16A may translocate its activating $\mathrm{Ca}^{2+}$ source, i.e., the endoplasmic reticulum, by membrane tethering, and iii) unknown antagonistic accessory proteins may be stoichiometrically underrepresented in TMEM16A-overexpressing cells [23,24,38,39]. It is also entirely possible that temperature-sensitive $\mathrm{Ca}^{2+}$-permeable transient receptor potential (TRP) channels are involved in the temperature-sensitive activation of TMEM16A [40-42]. Notably, TRP channels have also been shown to be regulated by $\mathrm{PIP}_{2}$ and CAM [43,44]. Alternatively, other accessory proteins may interact differentially under overexpressed or endogenous conditions [24].

Pre-association of $\mathrm{Ca}^{2+}$-free CAM (apoCAM) may preferentially occur with overexpressed TMEM16A and thus sensitize the channel for intracellular $\mathrm{Ca}^{2+}[3,4]$. Accordingly, the benzimidazolone 1-EBIO may then promote the association between apoCAM and TMEM16A. 1-EBIO is a known activator of $\mathrm{Ca}^{2+}$ sensitive SK-channels [45,46]. SK channels, e.g., $\mathrm{KCNN} 4$, consist of a $\alpha$-subunit that requires $\mathrm{CAM}$ as $\beta$-subunit to gate the channel upon binding of $\mathrm{Ca}^{2+}$ to CAM. 1-EBIO enhances the interaction between the $\alpha$-subunit and $\mathrm{CAM}$ and thereby shifts the $\left[\mathrm{Ca}^{2+}\right]_{i} /$ channel activity-relationship to lower $\left[\mathrm{Ca}^{2+}\right]_{i}[47]$. Notably, 1-EBIO did not activate any SK currents in the absence of $\left[\mathrm{Ca}^{2+}\right]_{i}[47]$, and similarly, TMEM16A was not spontaneously active and was not activated by 1-EBIO in the absence of cytosolic (pipette) $\mathrm{Ca}^{2+}$ (Figure 1).

Association of a B-subunit such as holoCAM or apoCAM with TMEM16A may not be surprising, given the recent findings of an association of the $\mathrm{KCNQ1}-\mathrm{K}^{+}$channel $\mathrm{B}$-subunit KCNE1 with TMEM16A [48]. Nevertheless, activation of TMEM16A by benzimidazolone compounds and the effects of CAM-regulated CAMKII or calcineurin were very moderate in epithelial cells with endogenous expression of TMEM16A. Taken together, it appears indispensable to examine whether activation by CAM and other accessory proteins/Bsubunits [48], phosphatidylinositols, temperature or small molecule activators, respectively, does exist for endogenous channels expressed in non-cultured cells and tissues under physiological conditions.

Author Contributions: Conceptualization, K.T., J.O., R.C., R.S., and K.K.; methodology, K.T., J.O., R.C., and R.S.; formal analysis, K.T., J.O., R.C., R.S., and K.K.; investigation, K.T., J.O., R.C., R.S., and K.K.; data curation, K.T., J.O., R.C., R.S., and K.K.; writing-original draft preparation, K.K.; writing - review and editing, K.K. All authors have read and agreed to the published version of the manuscript.

Funding: This research was supported by the Deutsche Forschungsgemeinschaft (DFG, German Research Foundation), project number 387509280, SFB 1350 (project A3), UK CF Trust SRC013, DFG KU756/14-1, and Gilead Stiftung.

Institutional Review Board Statement: Not Applicable.

Informed Consent Statement: Not Applicable.

Acknowledgments: We thank Luis Galietta (Telethon Institute of Genetics and Medicine, Pozzuoli, Italy) for providing the $\mathrm{HT}_{29}$ /YFP cells and Ron Chrystal (Weill Cornell Medical College, New York, NY, USA) for providing the BCi-NS1 cell line. We thank Yuemin Tian for experimental assistance.

Conflicts of Interest: The authors declare no conflict of interest.

\section{References}

1. Tian, Y.; Kongsuphol, P.; Hug, M.; Ousingsawat, J.; Witzgall, R.; Schreiber, R.; Kunzelmann, K. Calmodulin-dependent activation of the epithelial calcium-dependent chloride channel TMEM16A. FASEB J. 2011, 25, 1058-1068. [CrossRef] [PubMed]

2. Jung, J.; Nam, J.H.; Park, H.W.; Oh, U.; Yoon, J.H.; Lee, M.G. Dynamic modulation of ANO1/TMEM16A HCO3- permeability by Ca2+/calmodulin. Proc. Natl. Acad. Sci. USA 2013, 110, 360-365. [CrossRef] [PubMed] 
3. Yang, T.; Hendrickson, W.A.; Colecraft, H.M. Preassociated apocalmodulin mediates Ca2+-dependent sensitization of activation and inactivation of TMEM16A/16B Ca2+-gated Cl-channels. Proc. Natl. Acad. Sci. USA 2014, 111, 18213-18218. [CrossRef]

4. Yang, T.; Colecraft, H.M. Calmodulin regulation of TMEM16A and 16B Ca2+-activated chloride channels. Channels 2015, 10, 38-44. [CrossRef] [PubMed]

5. Vocke, K.; Dauner, K.; Hahn, A.; Ulbrich, A.; Broecker, J.; Keller, S.; Frings, S.; Möhrlen, F. Calmodulin-dependent activation and inactivation of anoctamin calcium-gated chloride channels. J. Gen. Physiol. 2013, 142, 381-404. [CrossRef]

6. Yu, Y.; Chen, T.-Y. Purified human brain calmodulin does not alter the bicarbonate permeability of the ANO1/TMEM16A channel. J. Gen. Physiol. 2015, 145, 163. [CrossRef]

7. Yu, K.; Zhu, J.; Qu, Z.; Cui, Y.-Y.; Hartzell, H.C. Activation of the Ano1 (TMEM16A) chloride channel by calcium is not mediated by calmodulin. J. Gen. Physiol. 2014, 143, 253-267. [CrossRef]

8. Wagner, J.A.; Cozens, A.L.; Schulman, H.; Gruenert, D.C.; Stryer, L.; Gardner, P. Activation of chloride chanels in normal and cystic fibrosis airway epithelial cells by multifunctional calcium/calmodulin- dependent protein kinase. Nature 1991, 349, 793-796. [CrossRef]

9. Worrell, R.T.; A Frizzell, R. CaMKII mediates stimulation of chloride conductance by calcium in T84 cells. Am. J. Physiol. Content 1991, 260, 877. [CrossRef]

10. McGill, J.; Yen, M.; Basavappa, S.; Mangel, A.; Kwiatkowski, A. ATP-Activated Chloride Permeability in Biliary Epithelial Cells Is Regulated by Calmodulin-Dependent Protein Kinase II. Biochem. Biophys. Res. Commun. 1995, 208, 457-462. [CrossRef]

11. Xie, W.; Kaetzel, M.A.; Bruzik, K.S.; Dedman, J.R.; Shears, S.; Nelson, D.J. Inositol 3,4,5,6-Tetrakisphosphate Inhibits the Calmodulin-dependent Protein Kinase II-activated Chloride Conductance in T84 Colonic Epithelial Cells. J. Biol. Chem. 1996, 271, 14092-14097. [CrossRef]

12. Schlenker, T.; Fitz, J.G. Ca(2+)-activated C1- channels in a human biliary cell line: Regulation by Ca2+/calmodulin-dependent protein kinase. Am. J. Physiol. Liver Physiol. 1996, 271, G304-G310. [CrossRef]

13. Wang, Y.-X.; Kotlikoff, M.I. Inactivation of calcium-activated chloride channels in smooth muscle by calcium/calmodulindependent protein kinase. Proc. Natl. Acad. Sci. USA 1997, 94, 14918-14923. [CrossRef] [PubMed]

14. He, X.-D.; Goyal, R.K. CaMKII inhibition hyperpolarizes membrane and blocks nitrergic IJP by closing a Cl- conductance in intestinal smooth muscle. Am. J. Physiol. Liver Physiol. 2012, 303, G240-G246. [CrossRef] [PubMed]

15. Lin, C.-X.; Lv, X.-F.; Yuan, F.; Li, X.-Y.; Ma, M.-M.; Liu, C.-Z.; Zhou, J.-G.; Wang, G.-L.; Guan, Y.-Y. Ca2+/Calmodulin-Dependent Protein Kinase II $\gamma$-Dependent Serine727 Phosphorylation Is Required for TMEM16A Ca2+-Activated Cl- Channel Regulation in Cerebrovascular Cells. Circ. J. 2018, 82, 903-913. [CrossRef] [PubMed]

16. Ayon, R.J.; Hawn, M.B.; Aoun, J.; Wiwchar, M.; Forrest, A.S.; Cunningham, F.; Singer, C.A.; Valencik, M.L.; Greenwood, I.A.; Leblanc, N. Molecular mechanism of TMEM16A regulation: Role of CaMKII and PP1/PP2A. Am. J. Physiol. Physiol. 2019, 317, C1093-C1106. [CrossRef] [PubMed]

17. Sánchez-Solano, A.; Corral, N.; Segura-Covarrubias, G.; Guzmán-Hernández, M.L.; Arechiga-Figueroa, I.; Cruz-Rangel, S.; Pérez-Cornejo, P.; Arreola, J. Regulation of the Ca2+-activated chloride channel Anoctamin-1 (TMEM16A) by Ca2+-induced interaction with FKBP12 and calcineurin. Cell Calcium 2020, 89, 102211. [CrossRef]

18. Greenwood, I.A.; LeDoux, J.; Leblanc, N. Differential regulation of Ca2+-activated $\mathrm{Cl}-$ currents in rabbit arterial and portal vein smooth muscle cells by Ca2+-calmodulin-dependent kinase. J. Physiol. 2001, 534, 395-408. [CrossRef]

19. Ko, W.; Suh, B.-C. Differential regulation of $\mathrm{Ca}^{2+}$-Activated $\mathrm{Cl}^{-}$Channel TMEM16A Splice Variants by Membrane PI(4,5) $\mathrm{P}_{2}$. Int . J. Mol. Sci. 2021, 22, 4088. [CrossRef]

20. Ko, W.; Jung, S.-R.; Kim, K.-W.; Yeon, J.-H.; Park, C.-G.; Nam, J.H.; Hille, B.; Suh, B.-C. Allosteric modulation of alternatively spliced Ca2+-activated $\mathrm{Cl}$-channels TMEM16A by PI(4,5)P2and CaMKII. Proc. Natl. Acad. Sci. USA 2020, 117, 30787-30798 [CrossRef]

21. Xie, W.; Solomons, K.R.H.; Freeman, S.; Kaetzel, M.A.; Bruzik, K.S.; Nelson, D.J.; Shears, S.B. Regulation of Ca2+-dependent $\mathrm{Cl}$-conductance in a human colonic epithelial cell line (T84): Cross-talk between Ins $(3,4,5,6)$ P4and protein phosphatases. $J$. Physiol. 1998, 510, 661-673. [CrossRef]

22. Ho, M.W.; Kaetzel, M.A.; Armstrong, D.L.; Shears, S.B. Regulation of a human chloride channel. a paradigm for integrating input from calcium, type ii calmodulin-dependent protein kinase, and inositol 3,4,5,6-tetrakisphosphate. J. Biol. Chem. 2001, 276, 18673-18680.

23. Tian, Y.; Schreiber, R.; Wanitchakool, P.; Kongsuphol, P.; Sousa, M.; Uliyakina, I.; Palma, M.; Faria, D.; E Traynor-Kaplan, A.; I Fragata, J.; et al. Control of TMEM16A by INO-4995 and other inositolphosphates. Br. J. Pharmacol. 2012, 168, 253-265. [CrossRef] [PubMed]

24. Centeio, R.; Cabrita, I.; Benedetto, R.; Talbi, K.; Ousingsawat, J.; Schreiber, R.; Sullivan, J.K.; Kunzelmann, K. Pharmacological Inhibition and Activation of the Ca2+ Activated Cl- Channel TMEM16A. Int. J. Mol. Sci. 2020, 21, 2557. [CrossRef] [PubMed]

25. Cabrita, I.; Benedetto, R.; Wanitchakool, P.; Lerias, J.; Centeio, R.; Ousingsawat, J.; Schreiber, R.; Kunzelmann, K. TMEM16A Mediates Mucus Production in Human Airway Epithelial Cells. Am. J. Respir. Cell Mol. Biol. 2021, 64, 50-58. [CrossRef] [PubMed]

26. Schreiber, R.; Uliyakina, I.; Kongsuphol, P.; Warth, R.; Mirza, M.; Martins, J.R.; Kunzelmann, K. Expression and Function of Epithelial Anoctamins. J. Biol. Chem. 2010, 285, 7838-7845. [CrossRef]

27. Lérias, J.; Pinto, M.; Benedetto, R.; Schreiber, R.; Amaral, M.; Aureli, M.; Kunzelmann, K. Compartmentalized crosstalk of CFTR and TMEM16A (ANO1) through EPAC1 and ADCY1. Cell. Signal. 2018, 44, 10-19. [CrossRef] 
28. Martins, J.R.; Faria, D.; Kongsuphol, P.; Reisch, B.; Schreiber, R.; Kunzelmann, K. Anoctamin 6 is an essential component of the outwardly rectifying chloride channel. Proc. Natl. Acad. Sci. USA 2011, 108, 18168-18172. [CrossRef]

29. Benedetto, R.; Centeio, R.; Ousingsawat, J.; Schreiber, R.; Janda, M.; Kunzelmann, K. Transport properties in CFTR-/- knockout piglets suggest normal airway surface liquid $\mathrm{pH}$ and enhanced amiloride-sensitive $\mathrm{Na}(+)$ absorption. Pflügers Arch. -Eur. J. Physiol. 2020, 472, 1507-1519. [CrossRef] [PubMed]

30. Tian, Y.; Schreiber, R.; Kunzelmann, K. Anoctamins are a family of Ca2+ activated Cl- channels. J. Cell Sci. 2012, 125, 4991-4998. [CrossRef]

31. Benedetto, R.; Ousingsawat, J.; Wanitchakool, P.; Zhang, Y.; Holtzman, M.J.; Amaral, M.; Rock, J.R.; Schreiber, R.; Kunzelmann, K. Epithelial Chloride Transport by CFTR Requires TMEM16A. Sci. Rep. 2017, 7, 1-13. [CrossRef] [PubMed]

32. De La Fuente, R.; Namkung, W.; Mills, A.; Verkman, A.S. Small-Molecule Screen Identifies Inhibitors of a Human Intestinal Calcium-Activated Chloride Channel. Mol. Pharmacol. 2008, 73, 758-768. [CrossRef] [PubMed]

33. Centeio, R.; Ousingsawat, J.; Schreiber, R.; Kunzelmann, K. CLCA1 Regulates Airway Mucus Production and Ion Secretion Through TMEM16A. Int. J. Mol. Sci. 2021, 22, 5133. [CrossRef] [PubMed]

34. Pedemonte, N.; Galietta, L. Structure and Function of TMEM16 Proteins (Anoctamins). Physiol. Rev. 2014, 94, 419-459. [CrossRef]

35. Whitlock, J.M.; Hartzell, H.C. Anoctamins/TMEM16 Proteins: Chloride Channels Flirting with Lipids and Extracellular Vesicles. Annu. Rev. Physiol. 2017, 79, 119-143. [CrossRef]

36. Suzuki, J.; Umeda, M.; Sims, P.J.; Nagata, S. Calcium-dependent phospholipid scrambling by TMEM16F. Nat. Cell Biol. 2010, 468, 834-838. [CrossRef]

37. Sirianant, L.; Ousingsawat, J.; Wanitchakool, P.; Schreiber, R.; Kunzelmann, K. Cellular volume regulation by anoctamin 6: Ca2+, phospholipase A2 and osmosensing. Pflügers Arch.-Eur. J. Physiol. 2015, 468, 335-349. [CrossRef] [PubMed]

38. Cabrita, I.; Benedetto, R.; Fonseca, A.; Wanitchakool, P.; Sirianant, L.; Skryabin, B.V.; Schenk, L.K.; Pavenstädt, H.; Schreiber, R.; Kunzelmann, K. Differential effects of anoctamins on intracellular calcium signals. FASEB J. 2017, 31, 2123-2134. [CrossRef]

39. Kunzelmann, K.; Cabrita, I.; Wanitchakool, P.; Ousingsawat, J.; Sirianant, L.; Benedetto, R.; Schreiber, R. Modulating Ca2+ signals: A common theme for TMEM16, Ist2, and TMC. Pflügers Arch.-Eur. J. Physiol. 2015, 468, 475-490. [CrossRef]

40. Takayama, Y.; Shibasaki, K.; Suzuki, Y.; Yamanaka, A.; Tominaga, M. Modulation of water efflux through functional interaction between TRPV4 and TMEM16A/anoctamin 1. FASEB J. 2014, 28, 2238-2248. [CrossRef]

41. Cho, H.; Yang, Y.D.; Lee, J.; Lee, B.; Kim, T.; Jang, Y.; Back, S.K.; Na, H.S.; Harfe, B.D.; Wang, F.; et al. The calcium-activated chloride channel anoctamin 1 acts as a heat sensor in nociceptive neurons. Nat. Neurosci. 2012, 15, 1015-1021. [CrossRef] [PubMed]

42. Hawn, M.B.; Akin, E.; Hartzell, H.; Greenwood, I.A.; Leblanc, N. Molecular Mechanisms of Activation and Regulation of ANO1-Encoded Ca2+-Activated Cl-Channels. Channels 2021. [CrossRef] [PubMed]

43. Hasan, R.; Leeson-Payne, A.; Jaggar, J.H.; Zhang, X. Calmodulin is responsible for Ca2+-dependent regulation of TRPA1 Channels. Sci. Rep. 2017, 7, srep45098. [CrossRef] [PubMed]

44. Zheng, W.; Cai, R.; Hofmann, L.; Nesin, V.; Hu, Q.; Long, W.; Fatehi, M.; Liu, X.; Hussein, S.; Kong, T.; et al. Direct Binding between Pre-S1 and TRP-like Domains in TRPP Channels Mediates Gating and Functional Regulation by PIP2. Cell Rep. 2018, 22, 1560-1573. [CrossRef]

45. Singh, S.; A Syme, C.; Singh, A.K.; Devor, D.C.; Bridges, R.J. Benzimidazolone activators of chloride secretion: Potential therapeutics for cystic fibrosis and chronic obstructive pulmonary disease. J. Pharmacol. Exp. Ther. 2001, 296, 600-611.

46. Devor, D.C.; Singh, A.K.; A Frizzell, R.; Bridges, R.J. Modulation of Cl- secretion by benzimidazolones. I. Direct activation of a $\mathrm{Ca}(2+)$-dependent K+ channel. Am. J. Physiol. Content 1996, 271, L775-L784. [CrossRef]

47. Pedarzani, P.; Mosbacher, J.; Rivard, A.; Cingolani, L.A.; Oliver, D.; Stocker, M.; Adelman, J.P.; Fakler, B. Control of Electrical Activity in Central Neurons by Modulating the Gating of Small Conductance Ca2+-activated K+ Channels. J. Biol. Chem. 2001, 276, 9762-9769. [CrossRef]

48. Prado, P.Á.; Häfner, S.; Comoglio, Y.; Wdziekonski, B.; Duranton, C.; Attali, B.; Barhanin, J.; Sandoz, G. KCNE1 is an auxiliary subunit of two distinct ion channel superfamilies. Cell 2020, 184, 534-544. [CrossRef] 